\title{
Pengaruh Motivasi terhadap Kinerja Guru Dimoderasi Gaya Kepemimpinan Transformasional dan Budaya Organisasional
}

\author{
Lustriningsih \\ Program Pasca Sarjana Universitas STIKUBANK Semarang \\ Email: lustrilustri1@gmail.com
}

\begin{abstract}
Article Info
Abstract

Article History

Received: 2020-11-17

Revised: 2021-01-05

Published: 2021-01-18

This study aims to axamine and analyze whether motivation influences teacher's performence, whether transformational leadership style influences on teacher's performence, whether organisational culture influences on teacher's performence, whether transformational leadership style moderates the influence of motivation on teacher's performence, and whether organisational culture moderates the influence of

Keywords: Motivation; trasformational leadership style; Organisational culture and teacher's performance. motivation on teacher's performance, The population of this research was the teachers of SMKN 1 Ampelgading and the teachers of SMKN 1 Petarukan Pemalang Regency, while samples used were 131 people as respondents by using proportional and accidental sampling technique. Data were analysed using multiple regression analysis. The Results of the research can be concluded that motivation has no impact on teacher's performence, transformational leadership style has negative and significant influence on teacher's performence. organizational culture has positive and significant influence on teacher's performence, transformational leadership style moderates the influence of motivation on teacher's performence, and organisational culture doesn't moderate the influence of motivation on teacher's performence.
\end{abstract}

\begin{tabular}{l}
\hline Artikel Info \\
\hline Sejarah Artikel \\
Diterima: 2020-11-17 \\
Direvisi: 2021-01-05 \\
Dipublikasi: 2021-01-18
\end{tabular}

Kata kunci:

Motivasi;

Gaya Kepemimpinan

Transformasional;

Budaya Organisasional dan Kinerja Guru.

\begin{abstract}
Abstrak
Penelitian ini bertujuan untuk menguji dan menganalisis apakah motivasi berpengaruh terhadap kinerja guru, apakah gaya kepemimpinan transformasional berpengaruh terhadap kinerja guru, apakah budaya organisasional berpengaruh terhadap kinerja guru, apakah gaya kepemimpinan transformasional memoderasi pengaruh motivasi terhadap kinerja guru dan apakah budaya organisasional memoderasi pengaruh motivasi terhadap kinerja guru, Populasi dari penelitian ini adalah guru SMK Negeri 1 Ampelgading dan SMK Negeri 1 Petarukan Kabupaten Pemalang, sedangkan sampel yang digunakan sebanyak 131 orang dengan teknik proportional dan eccidental sampling. Data dianalisis dengan analisis regresi berganda. Hasil penelitian dapat disimpulkan bahwa motivasi tidak berpengaruh signifikan terhadap kinerja guru, gaya kepemimpinan transformasional berpengaruh negatif dan signifikan terhadap kinerja guru, budaya organisasional berpengaruh positif dan signifikan terhadap kinerja guru, gaya kepemimpinan transformasional memoderasi pengaruh motivasi terhadap kinerja guru dan budaya organisasional tidak memoderasi pengaruh motivasi terhadap kinerja guru.
\end{abstract}

\section{PENDAHULUAN}

Kinerja guru adalah kinerja yang terkait dengan pelaksanaan proses pembelajaran, mengevaluasi dan menilai, menganalisis hasil penilaian, dan melaksanakan tindak lanjut hasil penilaian, (Permendiknas No. 16 Tahun 2007). Berbagai upaya yang dilakukan pemerintah untuk meningkatkan standar kompetensi guru dengan berbagai pendidikan dan pelatihan, tetapi kinerja guru masih belum optimal. Terkait dengan belum optimalnya kinerja guru, hal ini terjadi juga pada SMK Negeri 1 Ampelgading dan SMK Negeri 1 Petarukan yang diidentifikasikan salah satunya adalah menurunnya kualitas mutu keluaran pendidikan pada tiga tahun terakhir. Hal ini terakumulasi pada penurunan nilai rerata hasil ujian nasional di SMK Negeri 1
Ampelgading dan SMK Negeri 1 Petarukan Kabupaten Pemalang. Nilai hasil ujian nasional dapat dilihat pada tabel berikut:

Tabel 1. Nilai Hasil Ujian Nasional dalam Tiga (3) Tahun Terakhir

\begin{tabular}{cccccc}
\hline No & $\begin{array}{c}\text { Seko } \\
\text { lah }\end{array}$ & $\begin{array}{c}\text { Jml } \\
\text { Pese } \\
\text { rta }\end{array}$ & $\begin{array}{c}\text { Rera } \\
\text { ta UN } \\
\mathbf{2 0 1 7}\end{array}$ & $\begin{array}{c}\text { Rera } \\
\text { ta UN } \\
\mathbf{2 0 1 6}\end{array}$ & $\begin{array}{c}\text { Rera } \\
\text { ta UN } \\
\mathbf{2 0 1 5}\end{array}$ \\
\hline 1 & $\begin{array}{l}\text { SMK Negeri } 1 \\
\text { Ampelgading }\end{array}$ & 696 & 63,76 & 65,02 & 71,6 \\
\hline 2 & $\begin{array}{l}\text { SMK Negeri } 1 \\
\text { Petarukan }\end{array}$ & 465 & 60,32 & 62,28 & 65,58 \\
\hline
\end{tabular}

Sumber : http://puspendik kemdikbud.go.id/hasil.un

Pemimpin transformasional adalah pemimpin yang menginspirasi para pengikutnya untuk 
mengenyampingkan kepentingan pribadi mereka demi kebaikan organisasi dan mereka mampu memiliki pengaruh yang luar biasa pada diri para pengikutnya, menyenangkan hati dan menginspirasi para pengikutnya untuk bekerja keras guna mencapai tujuan-tujuan bersama (Robbins dan Judge 2008).

Berbagai penelitian menunjukan bahwa Kepemimpinan Transformasional terhadap kinerja guru hasilnya belum konsisten atau masih ada gaps. Hasil review penelitian sebelumnya menyatakan bahwa Kepemimpinan Transformasional berpengaruh positif dan signifikan terhadap kinerja, Penelitian yang dilakukan oleh Pratama (2016), Muzaeni (2015), Susilowati (2015), Rahardjo (2014), serta Suweno \& MD Rahardian (2012), bahwa Kepemimpinan Transformasional berpengaruh positif dan signifikan terhadap kinerja. Berbeda dengan hasil penelitian dari Munasih (2015), bahwa kepemimpinan transformasional tidak berpengaruh terhadap kinerja guru. Faktor kedua yang mempengaruhi kinerja, adalah motivasi.

Motivasi kerja guru merupakan faktor yang mendorong seorang guru untuk melaksanakan tugasnya dengan penuh tanggung jawab, sehingga akan memperoleh hasil kerja maksimal. Di dalam dunia pekerjaan di segala bidang termasuk bidang pendidikan, motivasi memiliki peranan yang sangat penting, seseorang akan bekerja lebih giat dan tekun, apabila memiliki motivasi yang tinggi dalam dirinya. Review hasil penelitian sebelumnya menunjukan bahwa motivasi kerja berpengaruh positif dan signifikan terhadap kinerja. Hasil penelitian yang dilakukan oleh Sewang (2016), Onanda (2015), Ekosusilo \& Soepardjo (2014), Muhsin \& Y. Sutomo (2014), Syafrawi \& Heru Suprihhadi (2017), Yulaizah (2014), Meindinyo R. OK \& Ikurite N (2017), Handoyo et al. (2015), menunjukan bahwa motivasi kerja berpengaruh positif dan signifikan terhadap kinerja dan hasil penelitian yang dilakukan Tampi (2014), menunjukan bahwa secara simultan gaya kemimpinan dan motivasi berpengaruh positif dan signifikan terhadap kinerja, serta hasil penelitian Aditya \& Rini Nugraheni (2014), menunjukan bahwa motivasi berpengaruh positif terhadap kinerja karyawan dimoderasi budaya organisasi.

Berbeda dengan hasil penelitian yang dilakukan oleh Liana et al. (2016) dan Sunarto (2016), bahwa motivasi tidak berpengaruh positif terhadap kinerja guru. Selain gaya kepemimpinan transformasional dan motivasi yang berpengaruh terhadap kinerja, faktor ketiga yang mempengaruhi kinerja guru adalah budaya sekolah. Budaya sekolah yang konsisten akan meningkatkan kinerja guru secara optimal. Setiap individu dalam organisasi tidak lepas dari hakekat nilai-nilai budaya yang dianutnya, yang akhirnya akan bersinergi dengan perangkat organisasi, teknologi, sistem, strategi dan gaya hidup kepemimpinan.

Menurut Zubaedah (2015), budaya sekolah merupakan jiwa (spirit) sebuah sekolah yang memberikan makna terhadap kegiatan kependidikan sekolah tersebut, jika budaya sekolah kuat maka akan menjadi fasilitator bagi peningkatan sekolah yang efektif. Hasil Penelitian Pusat Informatika Departemen Pendidikan dan Kebudayaan, menunjukkan bahwa Guru yang berkualitas mempunyai hubungan dengan kualitas pendidikan (Depdikbud,1994). Oleh karena itu betapa pentingnya pembinaan profesional Guru. Hasil review penelitian terdahulu menunjukan bahwa budaya mempunyai korelasi positif dan signifikan terhadap kinerja.

Menurut Penelitian yang dilakukan oleh Arifin et al. (2015), Hakim \& Anwar Hadipapo (2015), Hutabarat (2015), bahwa budaya organisasi berpengaruh positif dan signifikan terhadap kinerja dan hasil penelitian Sihotang \& Zenyka Viedeyona Zebedeus (2013), menunjukan bahwa budaya memoderasi dan berpengaruh positif dan signifikan teradap kinerja. Berbeda dengan hasil penelitian yang dilakukan oleh Handoko et al. (2015), budaya organisasi tidak berpengaruh signifikan terhadap kinerja dan hasil penelitian yang dilakukan Yulaizah (2014), menunjukan budaya organisasi tidak memoderasi pengaruh motivasi terhadap kinerja.

Dari permasalahan di atas, maka peneliti tertarik untuk mengadakan penelitian dengan judul "Pengaruh Motivasi Terhadap Kinerja Guru Dimoderasi Gaya Kepemimpinan Transformasional dan Budaya Organisasional". Dan dapat dirumuskan permasalahan yaitu: Apakah Motivasi Berpengaruh Terhadap Kinerja Guru Dimoderasi Gaya Kepemimpinan Transformasional dan Budaya Organisasional?. Permasalahan tersebut dirinci menjadi beberapa pertanyaan penelitian sebagai berikut:

1) Apakah Motivasi berpengaruh terhadap kinerja guru?

2) Apakah Gaya Kepemimpinan Transformasional berpengaruh terhadap kinerja guru?

3) Apakah Budaya Organisasional berpengaruh terhadap kinerja guru?

4) Apakah Gaya Kepemimpinan Transformasional memoderasi pengaruh Motivasi terhadap kinerja guru?

5) Apakah Budaya Organisasional memoderasi pengaruh Motivasi terhadap kinerja guru?

Sedangkan Tujuan penelitian adalah: untuk menguji dan menganalisis pengaruh motivasi terhadap kinerja guru dimoderasi gaya kepemimpinan transformasional dan budaya organisasional.

\section{a) Motivasi}

Menurut Robbins (2010), motivasi berarti dorongan atau pemberian daya penggerak yang menciptakan kegairahan kerja seseorang agar mereka mau bekerja sama, bekerja efektif dan terintegrasi dengan segala daya upayanya untuk mencapai kepuasan. Motivasi merupakan faktor yang kehadirannya dapat menimbulkan 
kepuasan kerja dan meningkatkan kinerja karyawan. Berdasarkan pengertian motivasi di atas, dapat disimpulkan bahwa motivasi adalah dorongan yang timbul dalam diri seseorang untuk melakukan sesuatu, karena adanya rangsangan dari luar untuk memenuhi tanggung jawab atas tugas-tugas dalam organisasi untuk mencapai suatu tujuan.

\section{b) Gaya Kepemimpinan Transformasional}

Luthans (2011) mendefinisikan kepemimpinan sebagai sekelompok proses, kepribadian, pemenuhan, perilaku tertentu, persuasi, wewenang, pencapaian tujuan, interaksi, perbedaan peran, inisiasi struktur, dan kombinasi dari dua atau lebih dari hal-hal tersebut.

Khuntia \& Suar (2004) menegaskan bahwa pemimpin yang menerapkan kepemimpinan transformasional memberikan pengaruhnya kepada para pengikut dengan melibatkan pengikutnya berpartisipasi dalam penentuan tujuan, pemecahan masalah, pengambilan keputusan, dan memberikan umpan balik melalui pelatihan, pengarahan, konsultasi, bimbingan, dan pemantauan atas tugas yang diberikan oleh guru. Pemimpin transformasional adalah pemimpin yang mendorong para pengikutnya untuk merubah motif, kepercayaaan, nilai, dan kemampuan sehingga minat dan tujuan pribadi dari para pengikut dapat selaras dengan visi dan tujuan organisasi (Goodwin et al., 2001). Yukl (2010), mengemukakan bahwa para pemimpin transformasional membuat para pengikut menjadi lebih menyadari kepentingan dan nilai dari pekerjaan dan membujuk pengikut untuk tidak mendahulukan kepentingan diri sendiri demi organisasi. Dalam kajian yang berkenaan dengan profesi guru, dan kepemimpinan transformasional, para pengikut merasakan kepercayaan, kekaguman, kesetiaan dan penghormatan terhadap pemimpin. Menurut Robbins \& Judge (2008), terdapat empat komponen kepemimpinan transformasional, yaitu:

1) Idealized Influence (Pengaruh Ideal)

2) Inspirational Motivation (Motivasi Inspirasional)

3) Intellectual Stimulation (Stimulasi Intelektual)

4) Individualized Consideration (Pertimbangan Individual)

\section{c) Budaya Organisasional}

Menurut Robbins (2010), budaya
organisasional merupakan sistem makna
bersama yang dianut oleh anggota-anggota
yang membedakan suatu organisasi dari
organisasi lain. Sistem makna bersama ini, bila
diamati dengan lebih seksama, merupakan
seperangkat karakteristik utama yang dihargai
oleh suatu organisasi. Merujuk pada

pemikiran Luthans \& Edgar Schein (2011), budaya organisasi di sekolah terbagi dalam 6 dimensi yaitu dimensi (1) obeserved behavioral regularities; (2) norms; (3) dominant value; (4) philosophy; (5) rules dan (6) organization climate.

Menurut Zubaedah (2015), Salah satu masalah yang sangat serius dalam pendidikan di tanah air kita saat ini adalah rendahnya mutu pendidikan di berbagai jenis dan jenjang pendidikan. Kualitas pendidikan sebagai salah satu pilar pengembangan sumber daya manusia (SDM), bermakna strategis bagi pembangunan nasional. Keberhasilan sebuah lembaga pendidikan tidak hanya didukung oleh lengkapnya sarana dan prasarana, guru yang berkualitas ataupun input siswa yang baik, tetapi budaya sekolah sangat berperan terhadap peningkatan keefektifan sekolah.

Menurut Zubaedah (2015), budaya sekolah merupakan jiwa (spirit) sebuah sekolah yang memberikan makna terhadap kegiatan kependidikan sekolah tersebut, budaya sekolah yang kuat akan menjadi fasilitator bagi peningkatan sekolah yang efektif. Namun hal ini tidak terlepas dari motivasi kerja guru itu sendiri dan bagaimana kepemimpinan Kepala Sekolah tersebut dijalankan dengan baik. Menurut Zamroni (2011), memberikan batasan bahwa budaya sekolah adalah pola nilai-nilai, prinsiprinsip, tradisi-tradisi dan kebiasaan-kebiasaan yang terbentuk dalam perjalanan panjang sekolah, dikembangkan sekolah dalam jangka waktu yang lama dan menjadi pegangan serta diyakini oleh seluruh warga sekolah, sehingga mendorong munculnya sikap dan perilaku warga sekolah.

Budaya sekolah merupakan pola-pola yang mendalam, kepercayaan nilai, upacara, simbolsimbol dan tradisi yang terbentuk dari rangkaian, kebiasaan dan sejarah sekolah, serta cara pandang dalam memecahkan persoalanpersoalan yang ada di sekolah. Menurut Ahmad Sudrajat (2008), merujuk pada pemikiran Fred Luthans, \& Edgar Schein tentang dimensi budaya organisasi di sekolah, yaitu dimensi (1) obeserved behavioral regularities; (2) norms; (3) dominant value. (4) philosophy; (5) rules dan (6) organization climate.

\section{d) Kinerja Guru}

Hasibuan (2007) merumuskan kinerja atau prestasi kerja sebagai suatu hasil kerja yang dicapai seseorang dalam melaksanakan tugastugas yang dibebankan kepadanya yang didasarkan atas kecakapan, pengalaman kerja, dan kesungguhan serta waktu. Sentono (1999) mengatakan bahwa kinerja adalah hasil kerja yang dapat dicapai oleh seseorang atau sekelompok orang dalam suatu organisasi, sesuai dengan wewenang dan tanggung jawab masingmasing dalam rangka mencapai tujuan 
organisasi. Kinerja Guru adalah tingkat keberhasilan seseorang guru dalam melaksanakan tugas dan tanggung jawabnya serta kemampuan untuk mencapai tujuan dan standar yang telah ditetapkan (Sulistyorini, 2001).

Berdasarkan Pedoman Pelaksanaan Penilaian Kinerja Guru (PKG) yang dikeluarkan Kementerian Pendidikan Nasional Tahun 2010 menjelaskan bahwa aspek kinerja dalam pelaksanaan tugas utama guru adalah kinerja yang terkait dengan pelaksanaan proses pembelajaran bagi guru mata pelajaran atau guru kelas, meliputi kegiatan merencanakan dan melaksanakan pembelajaran, mengevaluasi dan menilai, menganalisis hasil penilaian, dan melaksanakan tindak lanjut hasil penilaian.

\section{e) Konsep Moderasi}

Ghozali (2016) menyatakan bahwa variabel moderasi (moderating) adalah variabel independen yang akan menguatkan atau melemahkan hubungan antara variabel independen lainnya terhadap variabel dependen. Baron \& David A. Kenny (1986) mendefinisikan moderator sebagai variabel kualitatif atau kuantitatif yang mempengaruhi arah dan atau kekuatan hubungan antara variabel independen dan dependen atau kriteria. Variabel moderasi ada 2 : (1) Quasi moderator adalah jika variabel moderator baik berinteraksi dengan variabel prediktor (dependen) dan secara langsung berkaitan dengan variabel kriteria; dan (2) Pure moderation adalah jika variabel moderator hanya berinteraksi dengan variabel prediktor (Baron \& David A. Kenny, 1986). Penelitian menggunakan moderasi tipe quasi moderator teknik interaksi.

\section{f) Hipotesis Penelitian}

1) Pengaruh Motivasi terhadap Kinerja Guru David McClelland (Robbins, 2010) dalam teorinya Mc.Clelland's Achievment Motivation Theory atau teori motivasi prestasi McClelland juga digunakan untuk mendukung hipotesis yang akan dikemukakan dalam penelitian ini. Konsep hubungan antara motivasi dengan kinerja dalam penelitian empiris menunjukkan bahwa motivasi berpengaruh terhadap kinerja. Dengan adanya motivasi yang tinggi akan meningkatkan kinerja guru, sebagaimana disampaikan oleh Sewang (2014), Onanda (2015), Tampi (2015), Maindinyo \& Ikurine N. (2017), Yulaizah (2014), Muhsin \& Y. Sutomo (2014), serta Syafrawi \& Heru Suprihhadi (2017), dalam hasil penelitiannya menyatakan bahwa ada pengaruh positif dan signifikan motivasi terhadap kinerja. Berdasarkan uraian di atas maka dapat diajukan hipotesis sebagai berikut:
H1: Motivasi berpengaruh positif terhadap Kinerja Guru.

2) Pengaruh Gaya Kepemimpinan Transformasional terhadap Kinerja Guru

Konsep awal tentang kepemimpinan transformasional dikemukakan oleh Bass 1997, yang menjelaskan bahwa kepemimpinan transformasional adalah sebuah proses dimana pimpinan dan para bawahannya, untuk mencapai tingkat moralitas dan motivasi yang lebih tinggi, para pemimpin transformasional mencoba menimbulkan kesadaran dari para pengikut dengan menentukan cita-cita yang lebih tinggi dan nilai-nlai moral seperti kemerdekaan, keadilan, dan bukan didasarkan atas emosi kemanusiaan, keserakahan, kecemburuan, atau kebencian.

Dari konsep penelitian empiris tersebut menunjukan bahwa gaya kepemimpinan transformasional berpengaruh positif terhadap kinerja, sebagaimana hasil penelitian yang dilakukan oleh Suweno \& MD Rahardhian (2012), Muzaeni (2015), Susilowati (2015), dan Pratama (2016), serta Rahardjo (2014) menunjukan bahwa kepemimpinan transformasional berpengaruh positif dan signifikan terhadap kinerja. Semakin baik gaya kepemimpinan transformasional Kepala Sekolah akan meningkatkan kinerja guru. Berdasarkan uraian di atas, maka dapat dirumuskan hipotesis sebagai berikut:

H2: Gaya Kepemimpinan Transformasional berpengaruh positif terhadap kinerja guru.

3) Pengaruh Budaya Organisasional terhadap Kinerja Guru

Menurut Robbins (2010), budaya organisasional merupakan sistem makna bersama yang dianut oleh anggota-anggota yang membedakan suatu organisasi dari organisasi lain. Sistem makna bersama ini, bila diamati dengan lebih seksama, merupakan seperangkat karakteristik utama yang dihargai oleh suatu organisasi. Dari penelitian empiris tersebut menunjukan bahwa budaya organisasional berpengaruh terhadap kinerja, sebagaimana hasil penelitian Arifin, et al (2014), Hutabarat (2015), Lathifah \& Anthon Rustono (2015), Hakim \& Anwar Hadipopo (2015), dan Awadh et al (2013), bahwa budaya organisasi berpengaruh positif dan signifikan terhadap kinerja. Semakin tinggi budaya organisasional dalam sebuah sekolah akan meningkatkan kinerja guru. Berdasarkan uraian di atas, maka dapat dirumuskan hipotesis sebagai berikut:

H3: Budaya Organisasional berpengaruh positif terhadap kinerja guru. 
4) Gaya Kepemimpinan Transformasional Memoderasi Pengaruh Motivasi Terhadap Kinerja Guru

Dengan adanya motivasi yang tinggi dari seorang guru akan meningkatkan kinerja, apalagi kalau motivasi yang tinggi tersebut didukung oleh tingginya gaya kepemimpinan transformasional yang baik, maka akan semakin meningkatkan kinerja guru. Sebagaiman hasil penelitian empiris yang dilakukan oleh Muzaeni (2015) dan Susilowati (2015), yang menyatakan bahwa kepemimpinan transformasional memoderasi pengaruh motivasi terhadap kinerja guru. Berdasarkan uraian di atas, maka dapat dirumuskan hipotesis sebagai berikut:

H4: Gaya kepemimpinan transformasional memoderasi pengaruh motivasi terhadap kinerja guru

5) Budaya Organisasional Memoderasi Pengaruh Motivasi Terhadap Kinerja Guru

Motivasi yang tinggi dari seorang guru akan meningkatkan kinerja, apalagi kalau motivasi tersebut didukung oleh budaya organisasional yang kuat, maka kinerja guru akan semakin optimal. Sebagaimana hasil penelitian empiris yang dilakukan oleh Aditya \& Rini Nugraheni (2014), Sihotang \& Zenyka Viedeyona Zebedeus (2013), yang menyatakan bahwa adanya pengaruh positif dan signifikan antara motivasi terhadap kinerja dengan dimoderasi budaya organisasi. Berdasarkan uraian di atas, maka dapat dirumuskan hipotesis sebagai berikut:

H5: Budaya organisasional memoderasi pengaruh motivasi terhadap kinerja guru.

\section{METODE PENELITIAN}

Populasi dalam penelitian ini adalah guru SMK Negeri 1 Ampelgading dan SMK Negeri 1 Petarukan Kabupaten Pemalang pada tahun pelajaran 2017/2018 yang berjumlah 196 orang. Sampel adalah bagian dari jumlah dan karakteristik yang dimiliki oleh populasi tersebut. Untuk itu sampel yang diambil dari populasi harus betul-betul representatif atau mewakili (Sugiyono, 2010). Untuk memenuhi standar error sampel, maka digunakan rumus Slovin.

\section{$\mathrm{n}=\mathrm{N} /\left(\mathbf{1}+\mathrm{Ne}^{2)}\right.$}

Keterangan :

$\mathrm{n}=$ Ukuran sampel $\mathrm{N}=$ Ukuran populasi

$\mathrm{e}=$ Tingkat kesalahan $5 \%$.

Maka sampelnya dapat dihitung sebagai berikut:

$$
\mathrm{n}=196 /\left(1+196 \times 0,05^{2}\right)
$$$$
\mathrm{n}=131 \text { orang }
$$

Prosedur proportional sampling digunakan untuk menentukan jumlah sampel dari masingmasing sub populasi guru SMK Negeri 1
Ampelgading (80 responden) dan SMK Negeri 1 Petarukan (51 responden). Sedangkan eccidental sampling digunakan untuk menentukan subjek sampel sebagai responden penelitian.

Sumber data dalam penelitian ini adalah data primer, yaitu data yang diperoleh langsung dari obyek yang diteliti yaitu guru-guru SMK Negeri 1 Ampelgading dan SMK Negeri 1 Petarukan Kabupaten Pemalang melalui penyebaran angket (kuesioner). Kuesioner yang digunakan dalam penelitian ini berisi dua bagian utama. Bagian pertama tentang identitas responden yang berisi data yang berhubungan dengan identitas responden dan keadaan sosial seperti : jenis kelamin, pendidikan terakhir, usia, masa kerja, dan golongan/kepangkatan. Sedangkan bagian kedua menyangkut instrument penelitian tentang Pengaruh Motivasi Terhadap Kinerja Guru di Moderasi Gaya Kepemimpinan Trasformasional dan Budaya Organisasional

Metode pengumpulan data yang digunakan dalam penelitian ini adalah menggunakan kuesioner yang merupakan suatu pengumpulan data dengan memberikan daftar pertanyaan kepada responden dengan harapan memberikan respon atas dasar pertanyaan tersebut (Umar, 2003). Kuesioner yang digunakan dalam penelitian ini dengan menggunakan skala Likert berbentuk cheklist yang berisi pertanyaan yang berhubungan dengan variabel-variabel penelitian dengan 5 alternatif jawaban.

\section{a) Teknik analisis}

Pada penelitian ini menggunakan model moderasi tipe quasi dengan teknik interaksi.

Model matematik :

$\mathrm{Y}=\beta 1 \mathrm{X}+\beta 2 \mathrm{Z} 1+\beta 3 \mathrm{Z} 2+\beta 4 \mathrm{X} * \mathrm{Z} 1+\beta 5 \mathrm{X} * \mathrm{Z} 2$

Keterangan:

$\mathrm{X}=$ motivasi

$\mathrm{Z} 1$ = gaya kepemimpinan transformasional

$\mathrm{Z2}$ = budaya organisasional

$\mathrm{Y}$ = kinerja guru

Interaksi $X^{*} \mathrm{Z} 1$ = moderasi_1

Interaksi $\mathrm{X}^{*} \mathrm{Z} 2$ = moderasi_2

\section{b) Uji Hipotesis (Uji t)}

Uji t pada dasarnya menunjukkan seberapa besar pengaruh satu variabel independen secara individual dalam menerangkan variasi variabel dependen (Ghozali, 2016). Pengujian melalui uji signifikansi dilakukan dengan menggunakan indikator signifikan 0,05. Jika signifikansi $<0,05$ maka hipotesis diterima, namun jika signifikansi $>0,05$ berarti hipotesis ditolak, (Ghozali, 2016).

\section{HASIL DAN PEMBAHASAN}

A. Hasil Penelitian

1) Uji Validitas

Uji validitas menunjukkan sejauh mana ketepatan dan kecermatan suatu alat ukur 
dapat mengukur suatu konstruk. Suatu kuesioner dikatakan valid, jika pertanyaan pada kuesioner mampu mengungkapkan sesuatu yang akan diukur oleh kuesioner tersebut (Ghozali, 2016). Berdasarkan hasil uji validitas pada setiap item pertanyaan hasil yang diperoleh sebagai berikut : untuk variabel motivasi (X) sebesar 0.867, variabel gaya kepemimpinan transformasional (Z1) sebesar 0.895, variabel budaya organisasional (Z2) sebesar 0.881 dan variabel Kinerja guru (Y) sebesar 0.869. semua KMO > 0,05 maka sampel dalam penelitian dianggap sudah mencukupi dan layak untuk dianalisis lebih lanjut. Sedangkan jika loading factor (component matrix) > 0,4 maka dinyatakan valid dan layak untuk dianalisis lebih lanjut.

\section{2) Uji Reliabilitas}

Uji reliabilitas digunakan untuk mengetahui sejauh mana data dapat memberikan hasil yang konsisten atau stabil dari waktu ke waktu bila dilakukan pengukuran kembali terhadap obyek atau responden. Suatu konstruk atau variabel dikatakan reliabel, jika memberikan nilai cronbach alpha $>0,7$. Berdasarkan hasil uji reliabilitas diperoleh nilai cronbach alpha : untuk variabel motivasi (X) sebesar 0,890, variabel gaya kepemimpinan transformasional (Z1) sebesar 0,947, variabel budaya organisasional (Z2) sebesar 0,959 dan variabel Kinerja guru (Y) sebesar 0,944.

Berdasarkan hasil uji reliabilitas diperoleh hasil dengan semua nilai cronbach alpha, masing-masing variabel $>0,7$. Jadi dapat disimpulkan bahwa instrumen motivasi (X), gaya kepemimpinan transformasional (Z1), Budaya Organisasional (Z2) dan kinerja guru (Y) dapat menghasilkan data yang reliabel.

3) Uji Normalitas

Model regresi dikatakan normal jika hasil uji Kolmogorov-Smirnov nilai asymp. Sig. (2-tailed) $=0,096>0,05$ artinya data telah terdistribusi normal.

4) Uji Heteroskedastisitas

Berdasarkan hasil uji heteroskedastisitas dapat diketahui bahwa variabel motivasi (sig) = 0.967, gaya kepemimpinan transformasional $(\operatorname{sig})=0.649$, budaya organisasional $(\mathrm{sig})=$ 0.590 .

5) Ujit

Unuk menjawab hipotesis dalam penelitian ini maka dilakukan Uji t melalui rumus Regresi Linear, seperti yang disajikan pada table berikut ini:
Tabel 2. Hasil Uji Hipotesis melalui analisis Regresi Linear

\begin{tabular}{lccc}
\multicolumn{1}{c}{ Model } & $\begin{array}{c}\text { Standar } \\
\text { dized } \\
\text { Coeffic } \\
\text { ients }\end{array}$ & $\begin{array}{c}t \\
\text { hitung }\end{array}$ & Sig. \\
& & 0.447 & 0.150 \\
(Constant) & 0.147 & 0.380 & 0.705 \\
Motivasi & -2.123 & -2.340 & 0.021 \\
Kep. Transf & 1.841 & 2.106 & 0.037 \\
Bud. Org & 2.918 & 2.249 & 0.026 \\
Motivasi ${ }^{*}$ Kep.Transf & -2.031 & -1.513 & 0.133 \\
Motivasi ${ }^{*}$ Bud. Org & & & \\
\hline
\end{tabular}

Analisis regresi menunjukkan bahwa; Motivasi tidak berpengaruh signifikan terhadap kinerja guru $(\beta=0,147$, sig $=0,705>0,05)$, maka hipotesis 1 (H1) yang dirumuskan bahwa motivasi berpengaruh positif dan signifikan terhadap kinerja guru, ditolak.

Gaya kepemimpinan transformasional berpengaruh negatif dan signifikan terhadap kinerja guru $(\beta=-2,123 \mathrm{sig}=0,021<0,05)$, maka hipotesis $2(\mathrm{H} 2)$ yang dirumuskan bahwa gaya kepemimpinan transformasional berpengaruh positif dan signifikan terhadap kinerja guru, ditolak.

Budaya organisasional terbukti mempunyai pengaruh positif dan signifikan terhadap kinerja guru $(\beta=1,841 \mathrm{sig}=0,037<0,05)$, maka hipotesis 3 (H3) yang dirumuskan bahwa budaya organisasional berpengaruh positif dan signifikan.

Interaksi antara motivasi dengan gaya kepemimpinan transformasional (sig) $=0.653$ dan interaksi antara motivasi dengan budaya organisasional (sig) $=0.659$, jadi semua variabel mempunyai nilai sig $>0.05$ berarti tidak terjadi heteroskedastisitas terhadap kinerja guru, diterima.

Gaya kepemimpinan transformasional terbukti memoderasi pengaruh motivasi terhadap kinerja guru $\quad(\beta=2,918 \mathrm{sig}=0,026$ $<$ 0,05), maka hipotesis 4 (H4) yang dirumuskan gaya kepemimpinan transformasional memoderasi pengaruh motivasi terhadap kinerja guru, diterima.

Budaya organisasionl terbukti tidak memoderasi pengaruh motivasi terhadap kinerja guru $(\beta=-2,031 \mathrm{sig}=0,133>0,05)$, maka hipotesis 5 (H5) yang dirumuskan bahwa Budaya organisasionl memoderasi pengaruh motivasi terhadap kinerja guru, ditolak.

Persamaan matematik moderasi quasi interaksi antara variabel dependen dan independen adalah: $\mathrm{Y}=0,147 \mathrm{X}-2,123 \mathrm{Z} 1+$ $1,841 \mathrm{Z2}+2,918 \mathrm{X}^{*} \mathrm{Z} 1-2,031 \mathrm{X}^{*} \mathrm{Z} 2$.

6) Uji F (Anova)

Hasil uji $\mathrm{F}$ (Goodness of Fit) menunjukan nilai $F=42.796$ (sig. $0.000<0,05$ ), berarti model regresi yang digunakan memenuhi persyaratan Goodness of Fit. 
7) Uji Koefisien Determinasi

Berdasarkan nilai Adjusted R Square sebesar 0,616 artinya $61,6 \%$ perubahan dari variabel kinerja guru dapat dijelaskan oleh varibel motivasi, gaya kepemimpinan transformasional, budaya organisasional serta hasil moderasi_1 dan moderasi_2. Sedangkan sisanya sebesar $38,4 \%$ dipengaruhi oleh variabel lain di luar model penelitian.

\section{B. Pembahasan}

Berdasarkan hasil analisis data dengan skala likert 5, variabel motivasi memiliki nilai mean 4,10 , berarti motivasi guru SMK Negeri 1 Ampelgading dan SMK Negeri 1 Petarukan sudah tinggi, namun demikian variabel motivasi dengan 14 indikator yang bersumber dari McClallend dalam Robins 2005, pada indikator ke 14 (X14) mempunyai nilai rata-rata (mean) terendah yaitu 3,64 yang berarti bahwa sebagian besar guru tidak suka memberikan arahan kepada rekan-rekan guru mengenai metode pembelajaran.

Kondisi empiris ini yang menyebabkan motivasi tidak berpengaruh terhadap kinerja guru. Hal ini mendukung hasil penelitian yang dilakukan oleh Liana et al (2016), dan Sunarto (2016), yang menyatakan bahwa motivasi tidak berpengaruh signifikan terhadap kinerja. Berdasarkan hasil analisis menunjukan gaya kepemimpinan transformasional berpengaruh negatif dan signifikan terhadap kinerja guru, hal ini berarti hipotesis dinyatakan ditolak. Salah satu faktor yang menjadi alasan hipotesis ini ditolak adalah bahwa gaya kepemimpinan transformasional tidak berpengaruh langsung terhadap kinerja, namun demikian gaya kepemimpinan transformasional memoderasi pengaruh motivasi terhadap kinerja guru. Terbukti bahwa pada deskripsi variabel menunjukan variabel gaya kepemimpinan transformasional memiliki mean sebesar 4,10 artinya rata-rata responden memilih jawaban setuju. Hal tersebut berarti persepsi responden terhadap gaya Kepemimpinan Transformasional relatif baik.

Namun demikian variabel gaya kepemimpinan transformasional dengan 20 indikator yang bersumber dari Bass (1997), pada indikator ke 7 (Z1.7) memiliki mean terendah yaitu sebesar 3,53 yang artinya bahwa sebagian besar responden beranggapan kepala sekolah kurang menampakkan kekuasaan dan rasa percaya diri. Hal ini disebabkan karena kepala sekolah SMK Negeri 1 Ampelgading dan SMK Negeri 1 Petarukan Kabupaten Pemalang merupakan kepala sekolah baru, yang juga baru di sekolah tersebut.

Kondisi empiris ini yang menjadikan gaya kepemimpinan transformasional berpengaruh negatif dan signifikan terhadap kinerja guru. Hal ini sesuai dengan hasil penelitian Nafiuddin (2014), bahwa gaya kepemimpinan transformasional berpengaruh negatif dan signifikan terhadap kinerja.

Berdasarkan hasil analisis menunjukan, budaya organisasional berpengaruh positif dan signifikan terhadap kinerja guru, hal ini berarti hipotesis dinyatakan diterima. Salah satu faktor yang menjadi alasan hipotesis ini diterima adalah sebagian besar responden berpersepsi baik terhadap budaya organisasional. Deskripsi variabel menunjukan bahwa variabel budaya organisasional memiliki nilai rata-rata pilihan jawaban responden (mean) sebesar 4,05 artinya rata-rata responden memilih jawaban setuju. Hal tersebut berarti persepsi responden terhadap budaya organisasional relatif baik.

Berdasarkan hasil uji regresi dan deskripsi variabel, kondisi empiris ini terjadi karena sebagian besar guru beranggapan bahwa budaya organisasional di Sekolah berjalan dengan baik. Hal ini mendukung hasil penelitian yang dilakkukan Arifin et al (2014), Hutabarat (2015), Lathifah \& Anthon Rustono (2015), Hakim \& Anwar Hadipopo (2015), dan Awadh et al (2013), bahwa budaya organisasional berpengaruh positif dan signifikan terhadap kinerja.

Berdasarkan hasil analisis gaya kepemimpinan transformasional memoderasi pengaruh motivasi terhadap kinerja guru, hipotesis diterima. Salah satu faktor yang menjadi alasan hipotesis ini diterima adalah sebagian besar responden berpersepsi baik terhadap gaya kepemimpinan transformasional. Berdasarkan hasil uji regresi dan deskripsi variabel, kondisi empiris ini terjadi karena sebagian besar guru menganggap bahwa gaya kepemimpinan transformasional dapat memperkuat pengaruh motivasi terhadap kinerja guru secara berkelanjutan. Hal ini mendukung hasil penelitian yang dilakkukan Muzaeni (2015), dan Susilowati (2015), bahwa pengaruh motivasi terhadap Kinerja Guru dimoderasi gaya kepemimpinan transformasional.

Hasil analisis regresi, menunjukan bahwa budaya organisasional berpengaruh negatif dan tidak memoderasi pengaruh motivasi terhadap kinerja guru, hal ini berarti hipotesis dinyatakan ditolak. Variabel budaya organisasional dengan 39 indikator yang bersumber dari Luthans (2010), pada indikator ke 19 (Z2.19) "Dalam rangka pencapaian mutu pendidikan di sekolah ini, sekolah sangat memperhatikan kesejahteraan guru, baik yang bersifat materi maupun non materi" dengan mean terendah yaitu 3,786.

Kondisi empiris ini terjadi karena sebagian besar responden beranggapan bahwa sekolah kurang memperhatikan kesejahteraan guru yang bersifat materi maupun non materi, sehingga budaya organisasional tidak menguatkan pengaruh motivasi terhadap kinerja guru. Hal ini mendukung hasil penelitian yang dilakukan oleh Yulaizah (2014), Muhsin \& Y. Sutomo (2014), dan 
Munasih (2015) budaya organisasional tidak memoderasi pengaruh motivasi terhadap kinerja.

\section{SIMPULAN DAN SARAN}

\section{A. Simpulan}

Berdasarkan hasil analisis data, uji hipotesis dan pembahasan; pengaruh motivasi terhadap kinerja guru dimoderasi gaya kepemimpinan transformasional dan budaya organisasional, dapat disimpulkan bahwa:

1) Motivasi tidak berpengaruh signifikan terhadap kinerja guru.

2) Gaya kepemimpinan transformasional berpengaruh negatif dan signifikan terhadap kinerja guru.

3) Budaya organisasional berpengaruh positif dan signifikan terhadap kinerja guru.

4) Gaya kepemimpinan transformasional memoderasi pengaruh motivasi terhadap kinerja guru.

5) Budaya organisasional tidak memoderasi pengaruh motivasi terhadap kinerja guru.

Keterbatasan Penelitian

Keterbatasan penelitian ini antara lain terletak pada hasil uji koefisien determinasi (Adjusted $R$ Square) dengan nilai 0,616 artinya hanya $61,6 \%$ perubahan dari variabel kinerja guru dapat dijelaskan oleh varibel motivasi, gaya kepemimpinan transformasional, budaya organisasional serta hasil moderasi_1 dan moderasi_2. Sedangkan sisanya sebesar 38,4\% dijelaskan/dipengaruhi oleh variabel lain di luar model penelitian.

\section{B. Saran}

Berdasarkan hasil penelitian mengenai pengaruh motivasi terhadap kinerja guru dimoderasi gaya kepemimpinan transformasional dan budaya organisasional, maka kami sarankan hal-hal sebagai berikut:

1) Kepala Sekolah hendaklah lebih menunjukan kekuasaan dan lebih percaya diri, sehingga akan meningkatkan kinerja guru.

2) Kepala Sekolah dan semua guru perlu menguatkan budaya organisasional sekolah, sehingga akan menguatkan pengaruh motivasi guru terhadap kinerja guru.

Implikasi Teoritis:

1) Hasil penelitian dapat memberikan kontribusi dalam menambah pemahaman mengenai faktor-faktor yang mempengaruhi kinerja guru.

2) Hasil penelitian dapat digunakan sebagai dasar para peneliti yang akan melakukan penelitian tentang faktor-faktor lain yang berhubungan dengan kinerja guru.

3) Hasil penelitian dapat memberikan masukan terhadap pengetahuan khususnya Manajemen Sumber Daya Manusia Pendidikan.
Implikasi Praktis:

1) Hasil penelitian dapat digunakan sebagai bahan pertimbangan dalam merumuskan kebijakan program pengembangan tenaga pendidik dan kependidikan terutama kepala sekolah agar dapat melaksanakan fungsi kepemimpinan yang strategis dan adaptatif sesuai dengan kondisi sekolah dan meningkatkan budaya organisasional yang baik sehingga kinerja guru menjadi maksimal.

2) Hasil penelitian dapat dipergunakan sebagai bahan pertimbangan dalam upaya meningkatkan budaya organisasional yang dapat mendorong efektivitas gaya kepemimpinan.

3) Hasil penelitian ini dapat digunakan sebagai dasar pemikiran untuk pengembangan penelitian di bidang pendidikan terutama yang terkait dengan kinerja guru, motivasi, budaya organisasional, dan gaya kepemimpinan transformasional kepala sekolah

\section{DAFTAR RUJUKAN}

Aditya, Pitra Yusuf \& Rini Nugraheni (2014). Pengaruh Motivasi Terhadap Kinerja Karyawan Dengan Budaya Organisasi Sebagai Variabel Moderating (Studi Pada PT. Randugarut Plastic Indonesia). Jurnal Studi Manajemen \& Organisasi 11 Undip Semarang.

Akhmad Sudrajat (2008). Media Pembelajaran (online). http://akhmadsudrajat; wordpress.com.

Arifin, Eka A, Djumahir \& Mintarti Rahayu (2014). Organizational Culture, Transformational Leadership, Work Engagement and Teacher's Performance : Test of a Model. International Journal pf Education and Reasearh vol. 2 No. 1 (Januari)

Awadh, Alharbi Mohammad \& Mohammed Saad Alyahya (2013). Impact of Organisasi Culture on Employee Performance. Internasional Review of Management and Busines Research Vol. 2 Issue. 1 (March)

Baron, Reuben M. \& David A. Kenny (1986). The Moderator-Mediator Variable Distinction in Social Psychological Research: Conceptual, Strategic, and Statistical Considerations. Journal of Pe nality and Social Psychology Copyright 1986 by the American Psychological Association, Inc. Vol. 51, No. 6,1173-1182

Bass, B. M. (1997). Two Decades of Research and Development in Transformational Leadership. European Journal of Work and Organizational Psychology Ekonomi Volume 7 no. 2

Depdikbud (1994). Kurikulum Pendidikan (GBPP). Jakarta; Depdikbud

Ekosusilo, Madyo \& Soepardjo (2014), Faktor Dominan yang Mempengaruhi Motivasi Kerja, Kinerja dan Kepuasan Kerja Guru SMA, Social Behavior And Personality, 2014, 42(1) 
Ghozali, Imam ( 2016). Aplikasi Analisis Multivariate dengan Program IBM SPSS. Semarang : Badan Penerbit Universitas Diponegoro

Goodwin et al. (2001). A Theoritical and Empirical Extension to the Transformasional Leadership Construct. Journal of Organizational Behavior. Vol. 22 No. 7: 759 -774

Hakim, Abdul \& Anwar Hadipapo (2015), Peran Kepemimpinan dan Budaya Organisasi Terhadap Kinerja Sumber Daya Manusia di Wawotobi. Journal Universitas Islam Sultan Agung Semarang.

Handoko, Yusuf., Margono Setiawan, Surachman \& Djumahir (2015). Organizational Culture, Job Satisfaction, Organizational Commitment, the Effect on Lecturer Performance. International Journal of Business and Management Invention Vol. 2 Issue 12 (Desember), 201X/24-30

Handoyo, Laura Natali., Djamhur Hamid \& M. Iqbal (2015). The Influence of Leadership Styles on Employee's Performance Through Work Motivation (An Organizational Study at Four Hotels in Malang). Jurnal Administrasi Bisnis $(J A B)$ Vol. 22 No. 1 Brawijaya University Malang

Hasibuan (2007). Manajemen Sumber Daya Manusia. Jakarta : Bumi aksara

Hutabarat, Wesly (2015). Investigasi of Teacher Job Performance Model: Organizational Culture, Work Motivation and Job Satisfaction. Canadian Center of Science and EducationAsian Social Science Vol. 11 No. 18,(Juni), $1911-2017$

Kemendiknas (2010). Pengembangan Pendidikan Budaya dan Karakter Bangsa. Jakarta; Puskur-balitbang, Kemdiknas

Khuntia \& Suar (2004). A Scale to Assess Ethical Leadership of Indian Private and Public Sector Managers. Journal of Business Ethics.

Kwapong, Lipsey Samuel Appiah., Emmanuel Opoku \& Fokuo Donyina (2015). The Effect of Motivation on the Performance of Teaching Staff in Ghanaian Polytechings :The Moderating Role of Education and Research Experince. Global Journal of Human Resource Management vol. 3 No. 6, (Nopember), 30-40

Lathifah, Atsti Fauzia Ulfana \& Anthon Rustono, SE. MM (2015). Pengaruh Budaya Organisasi Terhadap Kinerja Karyawan Madrasah Aliyah Negeri (MAN) Cimahi. Fakultas Ekonomi dan Bisnis, Universitas Telkom

Liana, Lie., Tristiana Rijanti \& Herdiyanto (2016), Pengaruh Motivasi dan Self Efficacy Terhadap Kinerja Guru Dimoderasi Gaya Kepemimpinan Transformasional. Jurnal Unisbank Semarang

Luthans (2011). Organization Behavior: An EvidenceBased Approach. Twelfth Edition. New York: McGraw-Hill,

Meindinyo R. OK \& Ikurite N (2017). Influence of Motivation on Teachers Performance In A
Local Goverment Area In Nigeria. IOSR Journal of Humanities

Muhsin, Nur \& Y. Sutomo (2014). Pengaruh Kepribadian dan Motivasi Kerja Terhadap Kinerja Guru Dimoderasi Budaya Organisasi Pada Madrasah Tsanawiyah Swasta Kecamatan Winong Kabupaten Pati. Jurnal Unisbank Semarang

Munasih, Siti (2015), Pengaruh Motivasi Intrisik Terhadap Kinerja Guru dimodersasi Kepemimpinan Transformasional dan Budaya Organisasional (Studi Pada Guru SD Negeri Kecamatan Doro Kab. Pekalongan). Jurnal Unisbank Semarang

Muzaeni (2015). Pengaruh Motivasi dan Kompetensi Profesional Terhadap Kinerja Guru Dimoderasi Kepemimpinan Transformasional (Studi pada Guru SD PNS UPT Dindikbud Kecamatan Talun Kabupaten Pekalongan). Jurnal Unisbank Semarang

Nafiuddin, Yajid (2014). Pengaruh Motivasi Kerja dan Kepemimpinan Transformasional terhadap kinerja BTN Cabang Yogyakarta. Fakultas Ekonomi UNY

Onanda, Belly (2015). The Effects of Motivation on Job Performance A Case Study of KCB Coast Region. International Journal of scientific and Research Publications vol. 5 Issue 9 (September), 2250 $-3153$

Peraturan Menteri Pendidikan Nasional RI No. 16 Tahun 2007 tentang Standar Kualifikasi Akademik dan Kompetensi Guru.

Pratama, Gilang (2016). Effect of Transformational Leadership Towards Employee's Performance Through Satisfaction and Moderated by Culture. Jurnal Ekonomi Volume 7 no. 2

Rahardjo, Sri (2014). The Effect of Competence, Leadership and Work Environment Towards Motivation and Its Impact on the performance of Teacher of Elementary School in Surakarta City, Central Java, Indonesia. International Journal of Advanced Research in Management and Social Sciences Vol. 3 No. 6 (Juni), 2278 6236

Raharjo, Wiryo., \& Y. Sutomo (2016). Pengaruh Motivasi dan Kompetensi Profesional Terhadap Kinerja Kuru Dimoderasi Budaya Organisasional (Studi Kasus Pada Guru SMA Negeri Se-Kota Tegal). Jurnal Unisbank Semarang

Robbins \& Judge (2008). Perilaku Organisasi. Edisi xii Jakarta : Salemba Empat.

Robbins (2010). Essentials of Organizational Behavior. Edisi 10, Universitas Negeri San Diego.

Sentono (1999). Manajemen Sumber Daya Manusia Kebijakan Kinerja Karyawan. edisi 1, Yogyakarta: BPFE Yogyakarta.

Sewang, Anwar (2016), The Influence of Leadership Style, Organizational Culture, and Motivation on the Job Satisfaction and Lecturer's Performance at College of Darud Dakwah Wal 
Irsyad (DDI) at West Sulawesi. International Journal of Management and Administrative Sciences (IJMAS) Vol. 3, No. 05, (08-22)

Siagian (2002). Kepemimpinan Organisasi dan Perilaku Administrasi. Jakarta : Gunung Agung

Sihotang, Ronny Buha \& Zenyka Viedeyona Zebedeus (2013). Relationships between Total Quality Management Practices, Organizational Culture and Teacher's Performance : Study from Seventh Day Adventist High Schools in West Indonesia. International Research Journal of Business Studiesm Vol. 6 No. 2 ISSN 2089 6271

Simamora (2004). Manajemen Sumber Daya Manusia. Yogyakarta: STIE YKPN Yogyakarta.

Sobarna, A., Sunarsi, D., \& Roinadi, D. K. (2020). The Effect of Pedagogic Competence Kids Athletic toward Motivation for Elementary School. Solid State Technology, 63(6), 1364-1371.

Sugiyono (2012). Metode Penelitian Pendidikan. Bandung : Alfabeta

Sulistyorini (2001). Hubungan Antara Ketrampilan Manajerial Kepala Sekolah dan Iklim Organisasi dengan Kinerja Guru. Ilmu Pendidikan; 28 (1) 62-70.

Sunarsi, D. (2019). Penerapan MSDM Strategis Dalam Upaya Meningkatkan Kemampuan Organisasi dalam menyongsong Revolusi 4.0. Jurnal Ilmiah MEA (Manajemen, Ekonomi, \& Akuntansi), 3(1), 221-233. https://doi.org/10.31955/mea.vol3.iss1.pp2 21-233

Sunarsi, D. (2020). Panduan Meningkatkan Kinerja Dan Kepuasan Guru. Kota Serang: Desanta Muliavisitama

Sunarto (2016). Pengaruh Motivasi dan Kompetensi Profesional Terhadap Kinerja Guru Dimoderasi Komitmen Organisasional. Dinamika Journal Praktik Penelitian Tindakan
Kelas Pendidikan Dasar dan Menengah Vol. 6 No. 3 (April), 0894-217

Susilowati, Endah (2015). Pengaruh Motivasi dan Kompetensi Guru Terhadap Kinerja Guru Dimoderasi Kepemimpinan Transformasional (Study Kasus Pada MA di Kecamatan Winong Kab. Pati). Jurnal Unisbank Semarang

Sutrisno, S., \& Sunarsi, D. (2019). The Effect of Work Motivation and Discipline on Employee Productivity at PT. Anugerah Agung in Jakarta. Jurnal Ad'ministrare, 6(2), 187-196.

Syafrawi \& Heru Suprihhadi (2017). Pengaruh motivasi dan lingkungan kerja terhadap produktivitas karyawan dimoderasi budaya kerja. Jurnal Ilmu dan Riset Manajemen Volume 6, Nomor 10, Oktober 2017

Tampi, Bryan Johannes (2014). Pengaruh Gaya Kemimpinan dan Motivasi Terhadap Kinerja Karyawan pada PT. Bank Negara Indonesia, Tbk (Regional Sales Manado). Journal Acta Diurna vol. III No. 4

Umar (2003). Metode Riset Perilaku Konsumen Jasa. Jakarta : Ghalia Indonesia.

Yukl (2010). Kepemimpinan Dalam Organisasi. Edisi Indonesia, Jakarta. PT. Indeks

Yulaizah, Naniek (2014). Peran Budaya Organisasi Memoderasi Pengaruh Motivasi Kinerja Guru SMP Negeri di Kecamatan Taman Pemalang. Jurnal Unisbank Semarang

Zamroni (2011). Dinamika Peningkatan Mutu. Yogyakarta: Gavin Kalam Utama.

Zubaedah, Siti \& Aih Ervanti Ayuningtyas (2015). Pengaruh organisasi Untuk Meningkatkan Profesionalisme Guru di Sekolah. Prosiding Seminar Nasional Pendidiikan Ekonomi \& Bisnis FKIP UNS Surakarta. http://snpe.fkip.uns.ac.id. $\quad$ Sabtu, 07 September 2015. 